\title{
Sociodemographic Factors Associated with Delays in Breast Cancer
}

\author{
Mamour Gueye*, Serigne Modou Kane Gueye, Moussa Diallo, Ousmane Thiam, Aissatou Mbodji, \\ Aliou Diouf, Khalifa Fall, Youssou Toure, Hadja Maimouna Barro Daff, Jean Charles Moreau
}

Gynaecologic and Obstetric Clinic, Aristide Le Dantec Teaching Hospital, Dakar, Senegal

Email: *mamourmb@yahoo.fr

How to cite this paper: Gueye, M., Gueye, S.M.K., Diallo, M., Thiam, O., Mbodji, A., Diouf, A., Fall, K., Toure, Y., Daff, H.M.B. and Moreau, J.C. (2017) Sociodemographic Factors Associated with Delays in Breast Cancer. Open Journal of Obstetrics and Gynecology, 7, 455-463.

https://doi.org/10.4236/ojog.2017.74047

Received: January 17, 2017

Accepted: April 23, 2017

Published: April 26, 2017

Copyright $\odot 2017$ by authors and Scientific Research Publishing Inc. This work is licensed under the Creative Commons Attribution International License (CC BY 4.0).

http://creativecommons.org/licenses/by/4.0/

\begin{abstract}
Objectives: The aim of our study was to investigate the relation of some sociodemographic factors and delays presentation in breast cancer. Patients and method: This was an observational study in Breast Unit of Aristide Le Dantec Teaching Hospital in Dakar. Were included in the study all patients followed for breast cancer from January 2008 to December 2014. The following variables were selected and stratified: age, place of living, educational attainment, menopausal status, socioeconomic status and family history of breast cancer. For each variable, an association with the stage and presentation delay was assessed. Results: Two hundred and fifty nine (259) patients met the inclusion criteria. No correlation was found between the studied socio-demographic factors and delay. Negative history of family breast cancer was associated with presentation delay. The only factor associated with locally advanced breast cancer after adjusting confounding factors was low level of income. Conclusion: A significant percentage of women with breast cancer in Senegal are experiencing presentation delay. Coordinated efforts with public health department are needed to educate the focused groups and mitigate the barriers.
\end{abstract}

\section{Keywords}

Breast Cancer, Presentation Delay, Stage, Survival

\section{Introduction}

Breast cancer is now the most common female cancer and the leading cause of death among female cancers in developed countries [1]. In Senegal, it ranks second after cervix cancer [2].

In developing countries, breast cancer is often discovered at a late stage, which has a negative influence on prognosis [3]. 
Observations during our routine clinical practice have led us to note that poverty, social culture and lack of awareness about the disease can be factors leading to misconceptions and beliefs resulting in late consultation.

The objective of our study was to investigate the relationship between certain socio-demographic factors and the time for presentation, breast cancer diagnosis and survival.

\section{Patients and Method}

This was an observational study at Breast Unit of Aristide Le Dantec Teaching Hospital in Dakar. All patients followed for histologically proven breast cancer from January 2008 to December 2014 (7 years), were included in the study. The following variables were selected and stratified: age, place of living, educational attainment, menopausal status, socio-economic status and family history of breast cancer.

Age referred to age at diagnosis. It was stratified into 2 categories: $<40$ years and $\geq 40$ years.

The place of living was that where the patient had lived for at least 6 months at the time of diagnosis. Three categories were selected: patients living in Dakar and those living in countryside. The third category included patients living outside Senegal. They were excluded from the study.

Educational attainment was the highest level achieved. It was subdivided into different classes: illiterate, primary, middle and higher for those with a bachelor's degree. Secondly, two categories were chosen: uneducated (illiterate) and educated for the others.

Socioeconomic status was determined on the basis of monthly income (lowincome (monthly income in FCFA <35,000) or medium-high income (monthly income $\geq 35,000)$.

For all these variables, an association with stage, time to presentation and survival was sought.

Patients were classified into two stage categories: early stage: T1 and T2 (TNM classification of breast cancer, $7^{\text {th }}$ edition, 2010) and locally advanced stage (T3 and higher) [4].

The delay in diagnosis was defined as a time to presentation of 3 months or more since the onset of the first symptoms [6].

Data were extracted from our database, transferred to Microsoft Excel software and analysed with SPSS (Statistical Package for Social Science), version 21.0.

Chi-square test was used as a test of association between the variables. Survival curves were performed using Kaplan-Meier method.

\section{Results}

\section{1) Frequency}

Two hundred and fifty-nine (259) patients met the inclusion criteria out of 1891 patients followed for breast diseases leading to a frequency of $18.9 \%$. 


\section{2) Socio-demographic characteristics}

Our patients were relatively young: $60.6 \%$ of patients were under 40 years of age and $65.6 \%$ were premenopausal at diagnosis.

They were illiterated in almost half of cases $(46.3 \%)$. More than half came from countryside (51.4\%).

The income level was low in $79.2 \%$ of the cases.

The distribution of patients according to the socio-demographic level is reported in Table 1.

\section{3) Clinical features}

In almost all cases, patients consulted for a breast mass (91.5\%) with delayed presentation (78.4\%). The cancer was seen at a locally advanced stage in $80.7 \%$ of cases as shown in Table 2.

The negative family history of breast cancer was associated with delayed consultation.

There was no correlation between other socio-demographic factors such as age, place of residence, level of schooling and period of genital activity, and delay in consultation.

Table 1. Distribution of patients according to sociodemographic characteristics $(\mathrm{N}=$ 259).

\begin{tabular}{|c|c|c|}
\hline Variables & Number & Percentage \\
\hline \multicolumn{3}{|l|}{ Age } \\
\hline$<40$ years & 157 & 60.6 \\
\hline$\geq 40$ years & 102 & 39.4 \\
\hline \multicolumn{3}{|l|}{ Level of schooling } \\
\hline Illiterate & 120 & 46.3 \\
\hline Primary & 58 & 22.4 \\
\hline Intermediate & 47 & 18.1 \\
\hline High & 26 & 10 \\
\hline Unknown & 8 & 3.1 \\
\hline \multicolumn{3}{|l|}{ Place of living } \\
\hline Capital & 126 & 48.6 \\
\hline Countryside & 133 & 51.4 \\
\hline \multicolumn{3}{|l|}{ Income } \\
\hline Low & 205 & 79.2 \\
\hline Mid-High & 54 & 20.8 \\
\hline \multicolumn{3}{|l|}{ Menopausal status } \\
\hline Postmenopausal & 89 & 34.4 \\
\hline Premenopausal & 170 & 65.6 \\
\hline \multicolumn{3}{|c|}{ Family history of breast cancer } \\
\hline Yes & 35 & 13.5 \\
\hline No & 224 & 86.5 \\
\hline
\end{tabular}


Table 2. Distribution of patients according to clinical features.

\begin{tabular}{ccc}
\hline Variables & Number & Percentage \\
\hline Symptoms & 237 & \\
Breast mass & 22 & 91.5 \\
Other symptoms & & 8.5 \\
Time to presentation & 56 & 21.6 \\
$<3$ months & 203 & 78.4 \\
$\geq 3$ months & & \\
Stage & 15 & 5.8 \\
T1 & 35 & 13.5 \\
T2 & 111 & 42.9 \\
T3 & 98 & 37.8 \\
T4 & &
\end{tabular}

Table 3. Relation between sociodemographic characteristics, time to presentation and stage.

\begin{tabular}{|c|c|c|c|c|c|c|}
\hline \multirow[b]{2}{*}{ Variable } & \multicolumn{3}{|c|}{ Time of presentation } & \multicolumn{3}{|c|}{ Stage } \\
\hline & $<3$ months & $\geq 3$ months & $\mathrm{p}$ & ESBC & $\mathrm{ABC}$ & $\mathrm{p}$ \\
\hline \multicolumn{7}{|l|}{ Age } \\
\hline$<40$ years & $17(30.4)$ & 85 (41.9) & \multirow{2}{*}{0.07} & $20(19.6)$ & $82(80.4)$ & \multirow{2}{*}{0.8} \\
\hline$\geq 40$ years & $39(69.6)$ & $118(58.1)$ & & $32(20.4)$ & $125(79.6)$ & \\
\hline \multicolumn{7}{|l|}{ Income } \\
\hline Low & $43(76.8)$ & $162(79.8)$ & \multirow{2}{*}{0.6} & $36(17.6)$ & $169(82.4)$ & \multirow{2}{*}{0.04} \\
\hline Mid-High & $13(23.2)$ & $41(20.2)$ & & $16(29.6)$ & $38(70.4)$ & \\
\hline \multicolumn{7}{|l|}{ Schooling } \\
\hline Educated & $31(56.4)$ & $100(51)$ & \multirow[b]{2}{*}{0.5} & $32(24.4)$ & $99(75.6)$ & \multirow[b]{2}{*}{0.06} \\
\hline Illiterate & $24(43.6)$ & $96(49)$ & & $18(15)$ & $102(85)$ & \\
\hline \multicolumn{7}{|l|}{ Menopausal } \\
\hline Yes & $21(37.5)$ & $68(33.5)$ & \multirow{2}{*}{0.6} & $16(17.9)$ & $73(80.1)$ & \multirow{2}{*}{0.1} \\
\hline Now & $35(62.5)$ & $135(66.5)$ & & $36(21.2)$ & $134(78.8)$ & \\
\hline \multicolumn{7}{|c|}{ Family history of breast cancer } \\
\hline Yes & $13(23.2)$ & $22(10.8)$ & \multirow{2}{*}{0.01} & $9(25.7)$ & $26(74.3)$ & \multirow{2}{*}{0.3} \\
\hline No & $43(76.8)$ & $181(89.2)$ & & $43(19.2)$ & $181(80.8)$ & \\
\hline \multicolumn{7}{|l|}{ Place of living } \\
\hline Capital & $33(58.9)$ & $93(45.8)$ & \multirow[b]{2}{*}{0.05} & $29(23)$ & $97(77)$ & \multirow[b]{2}{*}{0.2} \\
\hline Countryside & $23(41.1)$ & $110(54.2)$ & & $23(17.3)$ & $110(82.7)$ & \\
\hline
\end{tabular}

ESBC: Early Stage Breast Cancer; ABC: Advanced Breast Cancer.

The only factor associated with advanced breast cancer after adjustment for confounding factors was low income. Table 3 shows the correlation between so- 
cio-demographic factors and clinical and prognostic features.

\section{4) Survival}

The mean survival time was 13.4 months for patients seen at an early stage and 15.5 months for those seen at a locally advanced stage while median survival was 6.9 and 2.2 months, respectively.

Table 4 and Figure 1 and Figure 2 show the mean and medians of survival.

\section{Discussion}

\section{1) Delayed presentation}

There is always an interval between first symptoms, diagnosis and the begin-

Table 4. Means and medians of survival times according to stage and time to presentation.

\begin{tabular}{ccccc}
\hline & \multicolumn{2}{c}{ Mean } & \multicolumn{2}{c}{ Median } \\
\hline & Mean & Confidence interval & Median & Confidence interval \\
\hline Time of presentation & & & & \\
$<3$ years & 16.982 & $11.136-22.828$ & 5.694 & $4.670-26.990$ \\
$>+3$ years & 15.041 & $12.464-17.617$ & 1.727 & $9.644-16.416$ \\
Stage & & & & \\
Early breast cancer & 13.467 & $5.750-21.183$ & 6.999 & $0.000-21.849$ \\
Advanced breast cancer & 15.599 & $13.113-18.085$ & 2.288 & $8.545-17.515$ \\
\hline
\end{tabular}

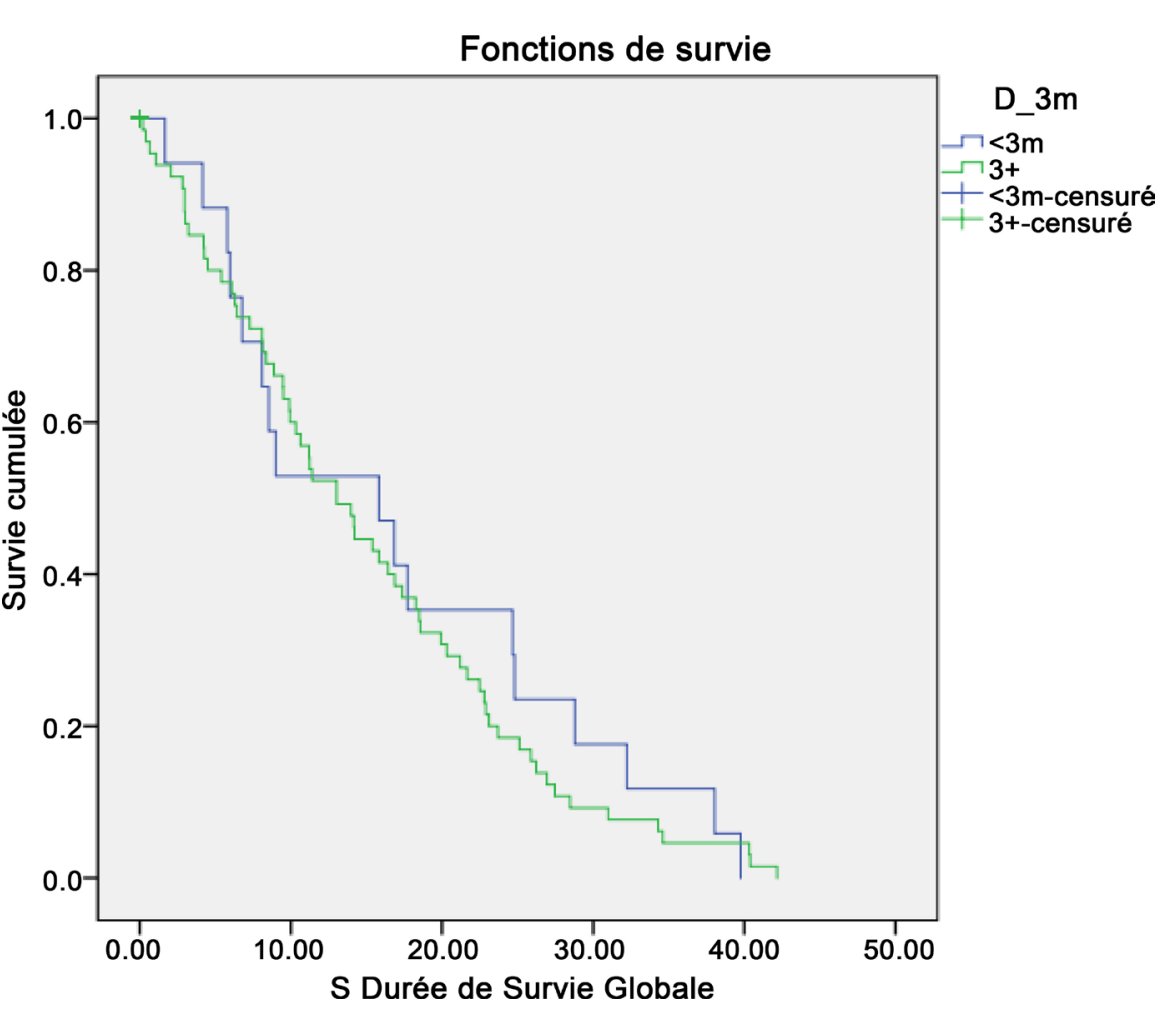

$<3$ months: Time to presentation $<3$ months; $3+$ : Time to presentation $>3$ months.

Figure 1. Survival curves using Kaplan Meier method according to stage and time to presentation. 


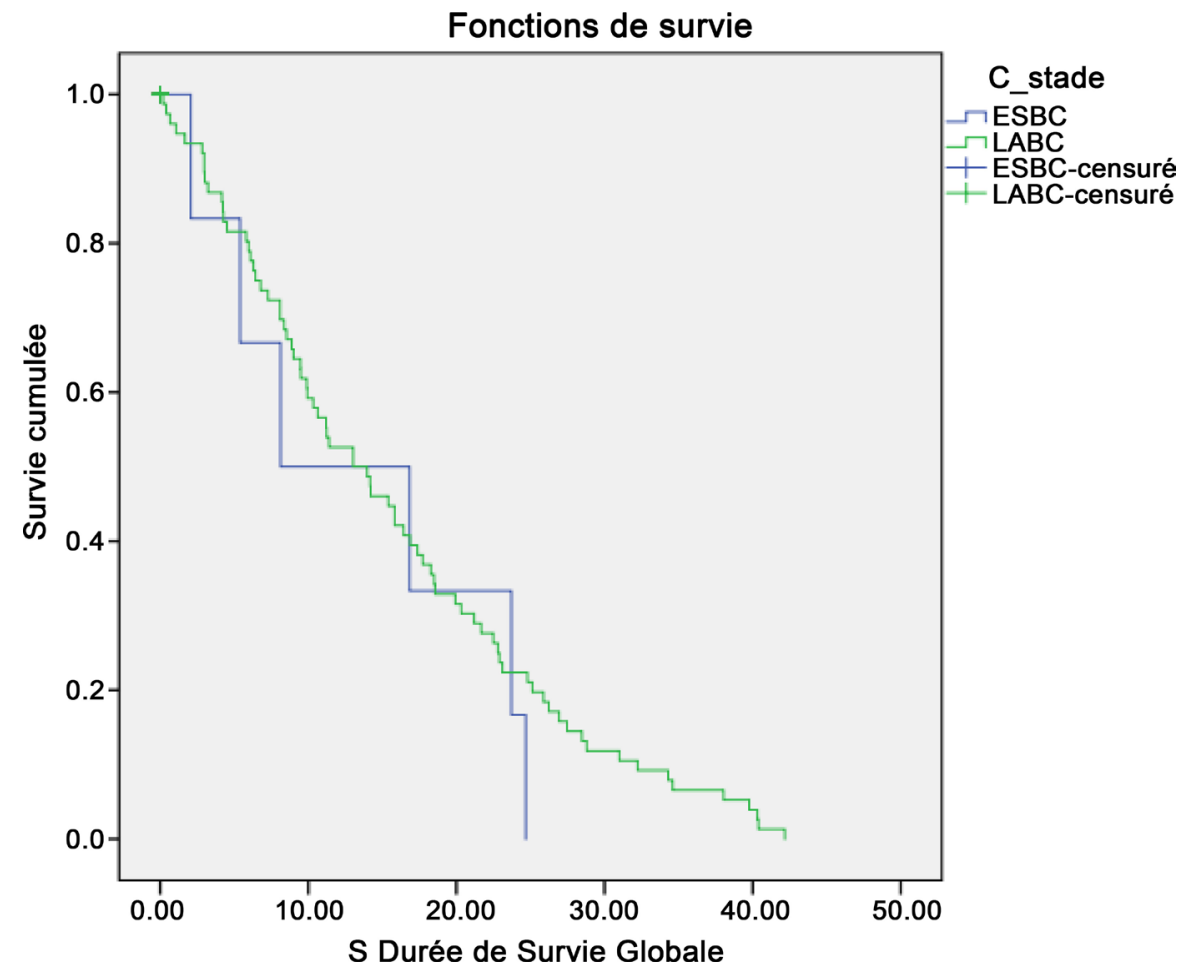

ESBC: T1 and T2; LABC: T3 and T4.

Figure 2. Survival curves using Kaplan Meier method according to stage.

ning of treatment in women with symptomatic breast cancer. This interval can be subdivided into three components: the time for presentation (first delay) and the time elapsed before starting treatment (third delay). The second delay is time elapsed between the moment the patient decides to consult and the meeting with the practitioner.

A systematic review of Richards et al. showed that delays of 3 to 6 months were clearly associated with a large tumour size at the time of diagnosis and a poor prognosis in the long term. Nevertheless, controversy persists as to the impact of the delay on survival. The contradictory results may be due to a difference in the characteristics of the sample, differences in the delay interval studied or variations in the delay definition [5].

However, it should be mentioned that data were exclusively based on interviews and not on registries. Data obtained on interviews may not be relevant.

\section{2) Factors associated to delayed presentation}

A breast mass rapidly growing may suggest a cancer in both doctors and patients while a mass of slow evolution may be less evident in patients and reassure them falsely. Our results revealed that $78.4 \%$ of patients were seen late according to our definition ( $>3$ months). The negative family history of breast cancer was associated with delayed consultation. Education and socio-economic status proved to be two independent factors related to delayed consultation. Our conclusions are similar to some other already published on the subject. In other studies conducted by Brzozowska et al. and other authors worldwide, delays longer than 3 months at the consultation are observed in proportions of $14 \%$ to $73 \%$ 
(mean of $33.1 \% \pm 19.5 \%$ DS) [6]-[11].

The most frequent reasons for delays reported by these studies were the painless nature of the breast mass, fear (abandonment by partner, cancer treatments, breast ablation), shyness, fatalism, therapeutics denial and inaccessibility to health services. Old age, a negative family history of breast cancer, low educational attainment and low socio-economic status were found to be the factors associated with a delayed consultation in these studies even though women with less financial resources are more likely not to seek health facilities [6]-[11].

In a multicentre prospective cohort study in the United States for women of 40 years of age or younger with breast cancer, $17 \%$ reported a delay in consultation that was associated with poorer financial status [12].

The level of schooling was not associated with delay in diagnosis or consultation beyond 3 months. These data are contradictory to other studies carried out in a similar context, such as Pace in Rwanda, where under-educated patients who consulted late had less information on breast disease, were not hampered by the manifestation of the disease or simply thought that the anomaly appeared would disappear spontaneously [13].

It is necessary to emphasize the important role played by the media in raising awareness of breast cancer, its manifestations and the interest of consultation without delay as soon as an anomaly appears in the breast. However, the lack of a positive relationship between the consultation period and schooling hides high rates of late consultation in both groups, which exceed $78 \%$.

A review by Freitas et al. aimed to analyse the main factors associated with delayed consultation. This review included 53 studies in developed countries (29 studies) and in development (24 studies). Three factors were found to explain the delay in consultation: non-attribution of symptoms to cancer, fear of illness and treatment, and low level of education. Age was not decisive in itself and depended mainly on the social and cultural context [14].

\section{3) Presentation delay and stage at diagnosis}

The impact of delays between onset of symptoms and onset of treatment on survival is controversial and cannot be studied in randomized controlled trials for ethical reasons. A systematic review of 87 observational studies around the world (101,954 patients) found that delays of 3 - 6 months were associated with lower survival rates [5].

$81.7 \%$ of our patients were diagnosed in stages III and IV, higher but closer to those reported in other developing countries such as Brazil, Egypt, India, Libya, Nigeria, Peru and Thailand, between $31 \%$ and $75 \%$ [15].

In industrialized countries such as Canada, Norway, Sweden and the United Kingdom, only between $8 \%$ and $22 \%$ of patients are diagnosed with locally advanced breast cancer [16].

Early diagnosis would greatly reduce the cost of cancer care, given the difficulties patients face in meeting the treatment challenges.

This approach involves a combination of strategies involving the community, health workers, and the health system. 
At a population level, strategies to improve the identification of symptoms of breast cancer are needed.

At a health system level, improved referral and admission procedures could facilitate the treatment of cancer.

\section{Conclusion}

A significant percentage of women with breast cancer in Senegal experience a delay. Coordinated efforts with public health units are needed to educate these patients and reduce the overall burden of disease in the country over the long term.

\section{Ethical Considerations}

The Dakar Teaching Hospital Ethical Committee approved this study.

\section{References}

[1] Alleman, I., Couvert-Mullot, H., Béranger, C. and Gisserot, O. (2010) Therapeutic Options for Hormone Receptor Negative Breastcancers. Le Praticien Hospitalier, 45, 25-32.

[2] Dem, A., Traoré, B., Dieng, M.M., Diop, P.S., Ouajdi, T., Lalami, M.T., et al. (2008) Breast and Gynecologic Tract Cancers in Curie Institute of Dakar, Senegal. Carnets de Santé, 18, 25-29.

[3] Guèye, M., Guèye, S.M.K., Mbaye, M., Dia, F.N., Diémé, M.E.F., Niang, M.M., et al. (2013) Clinical Features and Prognosis of Triple Negative Breast Cancer at the Senology Unit of Aristide-Le-Dantec Teaching Hospital. Journal Africain du Cancer, 5, 42-47.

[4] Edge, S.B., Byrd, D.R., Compton, C.C., Fritz, A.G., Greene, F.L. and Trotti, A. (2010) AJCC Cancer Staging Manual. 7th Edition, Springer, New York.

[5] Richards, M.A., Westcombe, A.M. and Love, S.B. (1999) Influence of Delay on Survival in Patients with Breast Cancer: A Systematic Review. The Lancet, 353, 1119 1126. https://doi.org/10.1016/S0140-6736(99)02143-1

[6] Brzozowska, A., Duma, D. and Mazurkiewicz, T. (2014) Reasons for Delay in Treatment of Breast Cancer Detected Due to Breast Self-Examination in Women from the Lubelskie Region. Ginekologia Polska, 85, 14-17. https://doi.org/10.17772/gp/1684

[7] Jones, C.E., Maben, J. and Jack, R.H. (2014) A Systematic Review of Barriers to Early Presentation and Diagnosis with Breast Cancer among Black Women. BMJ Open, 4, e004076. https://doi.org/10.1136/bmjopen-2013-004076

[8] Weinmann, S., Taplin, S.H., Gilbert, J., Weinmann, S., Taplin, S.H., Gilbert, J., et al. (2005) Characteristics of Women Refusing Follow-Up for Tests or Symptoms Suggestive of Breast Cancer. Journal of the National Cancer Institute. Monographs, 35, 33-38. https://doi.org/10.1093/jncimonographs/lgi035

[9] Montazeri, A., Ebrahimi, M. and Mehrdad, N. (2003) Delayed Presentation in Breast Cancer: A Study in Iranian Women. BMC Women's Health, 3, 4. https://doi.org/10.1186/1472-6874-3-4

[10] Ermiah, E., Abdalla, F. and Buhmeida, A. (2012) Diagnosis Delay in Libyan Female Breast Cancer. BMC Research Notes, 5, 452.

[11] Norsa'adah, B., Rampal, K.G. and Rahmah, M.A. (2011) Diagnosis Delay of Breast 
Cancer and Its Associated Factors in Malaysian Women. BMC Cancer, 11, 141. https://doi.org/10.1186/1471-2407-11-141

[12] Ruddy, K.J., Gelber, S., Tamimi, R.M., Ruddy, K.J., Gelber, S., Tamimi, RM., et al. (2014) Breast Cancer Presentation and Diagnostic Delays in Young Women. Cancer, 120, 20-25. https://doi.org/10.1002/cncr.28287

[13] Pace, L.E., Mpunga, T., Hategekimana, V., Dusengimana, J.M., Habineza, H., Bigirimana, J.B., et al. (2015) Delays in Breast Cancer Presentation and Diagnosis at Two Rural Cancer Referral Centers in Rwanda. Oncologist, 20, 780-788. https://doi.org/10.1634/theoncologist.2014-0493

[14] Freitas, A.G. and Weller, M. (2015) Patient Delays and System Delays in Breast Cancer Treatment in Developed and Developing Countries. Ciência \& Saúde Coletiva, 20, 3177-3189. https://doi.org/10.1590/1413-812320152010.19692014

[15] Unger-Saldana, K. (2014) Challenges to the Early Diagnosis and Treatment of Breast Cancer in Developing Countries. World Journal of Clinical Oncology, 5, 465477. https://doi.org/10.5306/wjco.v5.i3.465

[16] Olivotto, I.A., Gomi, A., Bancej, C., et al. (2002) Influence of Delay to Diagnosis on Prognostic Indicators of Screen-Detected Breast Carcinoma. Cancer, 94, 2143 2150. https://doi.org/10.1002/cncr.10453

Submit or recommend next manuscript to SCIRP and we will provide best service for you:

Accepting pre-submission inquiries through Email, Facebook, LinkedIn, Twitter, etc. A wide selection of journals (inclusive of 9 subjects, more than 200 journals) Providing 24-hour high-quality service User-friendly online submission system Fair and swift peer-review system Efficient typesetting and proofreading procedure Display of the result of downloads and visits, as well as the number of cited articles Maximum dissemination of your research work

Submit your manuscript at: http://papersubmission.scirp.org/

Or contact ojog@scirp.org 